UCRL-ID- 118926

\title{
Conceptual Design of a Raman Probe for Inclusion in the In-Tank Cone Penetrometer
}

Kevin R. Kyle

September 30, 1994

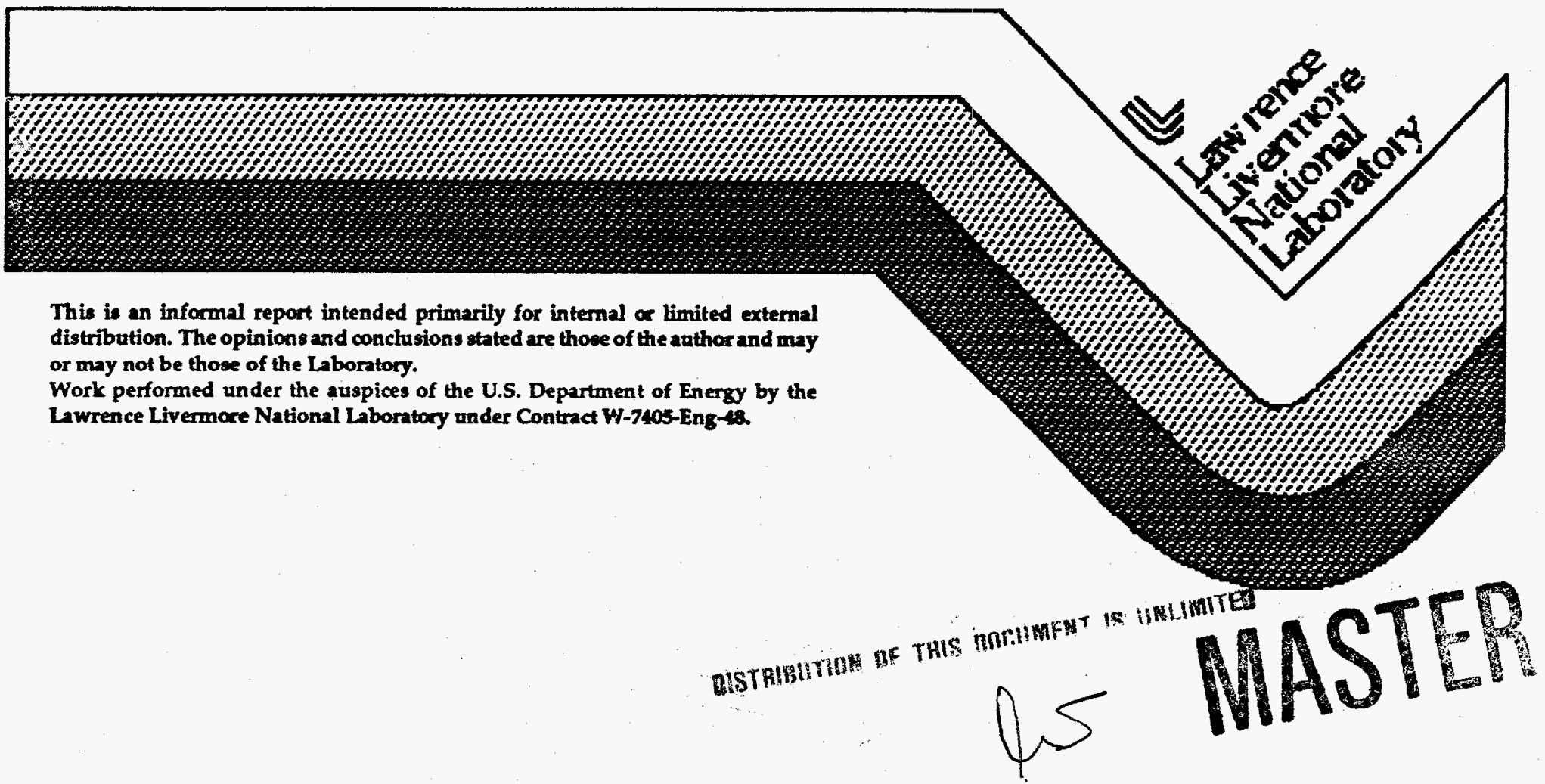




\section{DLSCLAMER}

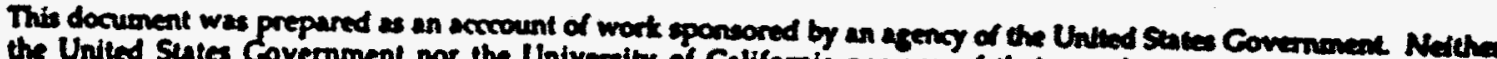
the United States Covernment nor the University of Collfomil nor any of their employes, mukes any warranty. informs or implied, or assumes any legal binbility or responsibility for the ancuracy, completenes or usetulness of any Reference herein lo any specific commerciel product or represents that ts use would not hifinge patvaldy own rights.

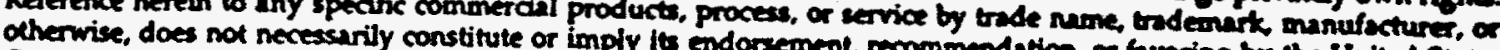
Covernment or the University of Califomi stale of reflect those of the United States Covemmeat and opinions of outhors expresed henein do nat neseavarity diverieting or product endorsement purposen.

This repart has been reproduced directly frow the beat avalible cops.

Availible to DOE and DOE contractors from the Office of Scientific and Technical Informution P.O. Box 62, Oak Ridge, IN 37231

Prices available from (615) 5768401 , FTS 626-840)

Available to the public froon the National Technical Information Service

US. Department of Commerce 5285 Port Royal Rd. Springfield, VA 22161

\section{DISCLAIMER}

This report was prepared as an account of work sponsored by an agency of the United States Government. Neither the United States Government nor any agency thereof, nor any of their employees, makes any warranty, express or implied, or assumes any legal liability or responsibility for the accuracy, completeness, or usefulness of any information, apparatus, product, or process disclosed, or represents that its use would not infringe privately owned rights. Reference herein to any specific commercial product, process, or service by trade name, trademark, manufacturer, or otherwise does not necessarily constitute or imply its endorsement, recommendation, or favoring by the United States Government or any agency thereof. The views and opinions of authors expressed herein do not necessarily state or reflect those of the United States Government or any agency thereof.

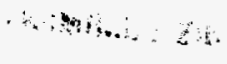




\section{DISCLAIMER}

Portions of this document may be illegible in electronic image products. Images are produced from the best available original document. 


\section{CONCEPTUAL DESIGN \\ of a \\ RAMAN PROBE for INCLUSION \\ in the \\ IN-TANK CONE PENETROMETER}

September 30, 1994

Kevin R. Kyle

Characterization and Detection Section

Environmental Technologies Program

Lawrence Livermore National Laboratory

This document has been submitted in fulfillment of Milestone Number 4 of the Technical Task Plan SF-2112-03, "Advanced Fiber Optic Spectroscopy for Inorganic Contaminants"

Technical Program Manager:

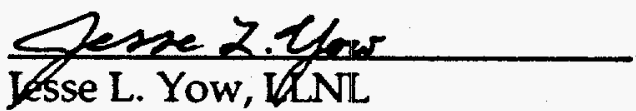

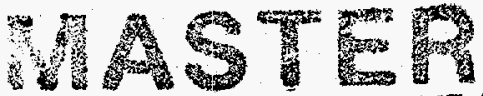

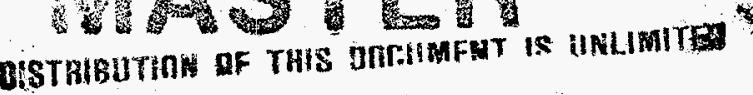

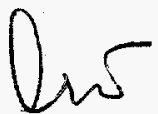




\section{CONTENTS}

$1.0 \quad$ INTRODUCTION $\ldots \ldots \ldots \ldots \ldots \ldots \ldots \ldots \ldots \ldots \ldots \ldots \ldots \ldots \ldots \ldots$

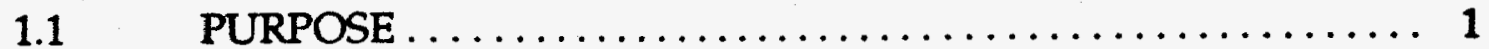

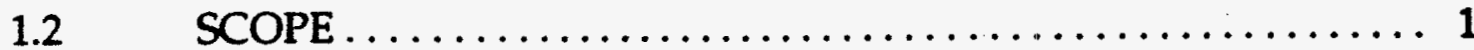

2.0 CONE PENETROMETER PROBE INTERFACE. $\ldots \ldots \ldots \ldots \ldots \ldots \ldots 2$

3.0 WINDOW MATERIALS $\ldots \ldots \ldots \ldots \ldots \ldots \ldots \ldots \ldots \ldots \ldots, \ldots \ldots$

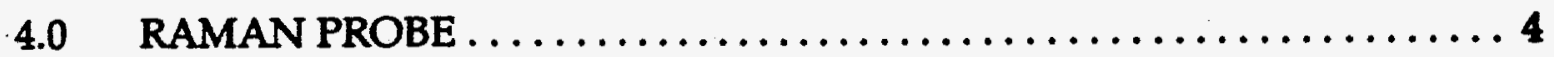

5.0 CONCLUSIONS $\ldots \ldots \ldots \ldots \ldots \ldots \ldots \ldots \ldots \ldots \ldots \ldots \ldots \ldots$

6.0 ACKNOWLEDGMENT $\ldots \ldots \ldots \ldots \ldots \ldots \ldots \ldots \ldots \ldots \ldots$

APPENDIX A $\quad$ FIGURES. $\ldots \ldots \ldots \ldots \ldots \ldots \ldots \ldots \ldots \ldots \ldots$ 
CONCEPTUAL DESIGN of a RAMAN PROBE for INCLUSION in the IN-TANK CONE PENETROMETER

\subsection{INTRODUCTION}

Lawrence Livermore National Laboratory (LLNL), in the Technical Task Plan (TTP) SF-2112-03 subtask 3, is responsible for the conceptual design of a Raman probe for inclusion in the in-tank cone penetrometer. LLNL is assigned the responsibility of generating a report describing recommendations for a robust Raman probe assembly that can be incorporated in the in-tank cone penetrometer for the chemical analysis of the potentially harsh tank environment. This probe would complement the capabilities of existing sensors for the physical characterization of the tank wastes and would give information on the chemical composition of the waste matrix. This work is part of a joint effort involving several DOE laboratories for the design and development of in-tank cone penetrometer deployable systems for direct UST waste characterization at Westinghouse Hanford Company (WHC) under the auspices of the U.S. Department of Energy (DOE) Underground Storage Tank Integrated Demonstration (UST-ID) and the Characterization, Monitoring, and Sensor Technology Integrated Program (CMST-IP).

\subsection{PURPOSE}

Currently, tank wastes are to be characterized by drilling and physically removing core samples. The cores are analyzed in laboratories in a hot cell environment. The purpose of the cone penetrometer is to bring the interrogative methods to the sample in its native environment, providing faster, safer, and more cost effective tank characterization, both in terms of time and effort. Probes currently exist for the physical characterization of tank wastes in terms of porosity, density, temperature, and electrical conductivity. The main tool for chemical analysis in the in-tank cone penetrometer will be a fiber optic Raman spectroscopy probe, which will be used to collect information about the molecular chemical constituents of the tank wastes. This report addresses the design and implementation of a Raman probe with the in-tank cone penetrometer.

\subsection{SCOPE}

A Raman probe deployed within a cone penetrometer must operate under conditions of high stress in terms of pressure, chemical attack, and radiation as sited in the document "Environmental Requirements for the Hanford Deployable, Cone Penetrometer Raman Spectroscopy Fiber Optic Probes" (WHC-SD-TD-RPT-008). A Raman probe assembly has been designed to address these conditions. The Raman probe itself will be shielded within the body of the penetrometer pipe, protecting it from carrying a high pressure load and chemical attack by the environment. The window which allows 
communication between the Raman probe optics and the waste surface outside of the penetrometer will be challenged by the caustic nature of the tank materials and the potential abrasiveness of the tank materials. Additionally, the window must be designed to withstand high compression shock generated from a 40 ton cone penetrometer.

The scope of this document includes design specifications and recommendations for the following aspects of the in-tank Raman cone penetrometer probe:

- Cone Penetrometer Probe Interface: An unit for the inclusion of a Raman probe in the in-tank cone penetrometer will be described.

- Window Materials: Chemically resistant and mechanically stable materials for the cone penetrometer probe interface window will be considered.

- Raman Probes:

the penetrometer will be discussed.

Raman probes for inclusion in

\subsection{CONE PENETROMETER PROBE INTERFACE}

The design concept of the Raman probe assembly for incorporation into the cone penetrometer is shown in Figures 1 through 3 of Appendix A. The design is based in part on the penetrometer nose plug of a cone penetrometer deployable TCE vapor sensor previously developed and successfully deployed by LLNL. The steel Raman probe assembly threads into the nose cone of the penetrometer at its bottom and into the penetrometer pipe at its top (Figure 1). The Raman probe assembly is designed to accept a Raman probe in its interior cavity (Figures 2 and 3 ) where the probe will be protected from both the pressure load of the penetrometer and the caustic environment of the tank waste material. The load of the penetrometer pipe is distributed over the exterior of the assembly, which is designed to be flush with the outer surface of the penetrometer. The flat optical window of the assembly lies flush with the surface of a milled flat area with radii at the top and bottom (Figure 2). A similar window design has been utilized by the laser induced fluorescence cone penetrometer probe.

The internal cavity of the Raman probe assembly is shown in Figure 3. A prism is mounted at the bottom of the Raman probe to establish optical communication between the Raman probe and the exterior of the penetrometer. The probe itself is housed within the hollow cylinder of the Raman probe assembly. The probe rests upon a projecting edge within the cylinder. The Raman probe is locked in place with a screw mounted cap. The assembly is designed for ease of alignment for the Raman probe prior to deployment. The assembly is also designed to allow flexibility in the choice of 
Raman probe to be deployed; the probe housing need only fit within the interior of the Raman probe assembly. The fiber optic cabling that connects the probe with both the laser source and Raman spectrograph will be threaded through the interior of the penetrometer pipe.

The cylindrical channel that serves as both the window housing and the optical pathway of the probe may also serve as the mount for glass focusing and/or collimating lenses if these are needed to maximize the field of view and/or collection efficiency of the Raman penetrometer probe (this parameter will be determined during FY95 under TTP SF2-1-12-03, subtask 1). The lens mount will be designed to float the lens within the Raman probe assembly so as to minimize the load transferred from the penetrometer to the less mechanically stable glass.

\subsection{WINDOW MATERIALS}

Materials were considered for their resistance to abrasion, their compression and tensile strengths, and their optical properities, including transparency and Raman spectra (Table 1). The compression and tensile strengths are an important consideration given the large compression shock generated by the penetrometer, up to 40 tons. Under this pressure, the steel cylindrical channel into which the window will be brazed and/or welded will tend to compress, in turn stressing the window. The calculated deflection of the metal over the diameter of the window is 0.00051 inches. The three available window materials were fused silica glass, sapphire ( $\alpha$-alumina, corundum), and diamond. Silica glass was determined to be inappropriate as a window material in terms of strength and abrasion resistance. However, its cost and ready commercial availabilty make it a useful material if lenses are required within the Raman probe assembly, but only under conditions where the lens is protected from the compression load of the penetrometer. The Raman spectrum of glass shows peaks at approximately $1200,1050,800,600,500$, and $425 \mathrm{~cm}^{-1}$, with the strongest peaks occuring below $1000 \mathrm{~cm}^{-1}$.

Both diamond and sapphire are suitable window materials in terms of hardness and optical transparency. The Raman spectrum of diamond consists of one peak at $1332 \mathrm{~cm}^{-1}$, with a FWHM of under $10 \mathrm{~cm}^{-1}$. The spectrum of sapphire consists of several peaks at $751,645,578,451,432,418$, and $378 \mathrm{~cm}^{-1}$, with the strongest peak occurring at $418 \mathrm{~cm}^{-1}$. The single line Raman spectrum and its superior hardness favor diamond as the choice of window material. At 20 tons of applied force, diamond has a safety factor of 5 (maximum allowable stress versus calculated stress). However, this diminishes at 40 tons, making diamond unsuitable. Sapphire retains its integrity at 20 and 40 tons, making it the window material of choice. Window dimensions utilized in the stress calculations were $7 \mathrm{~mm}$ diameter $(5 \mathrm{~mm}$ unsupported) by 0.5 to $1.2 \mathrm{~mm}$ thick. 
Table 1.

\begin{tabular}{|l|l|l|l|}
\hline Material & Fused Silica & Sapphire & Diamond \\
\hline Moh Hardness & 6 & 9 & 10 \\
\hline $\begin{array}{l}\text { Tensile Strength } \\
\text { (psi) }\end{array}$ & 7100 & 100000 & $1.5 \times 10^{8}$ \\
\hline $\begin{array}{l}\text { Compression } \\
\text { Strength (psi) }\end{array}$ & $1.66 \times 10^{6}$ & $3.0 \times 10^{6}$ & $1.3 \times 10^{6}$ \\
\hline Refractive Index & 1.45 & 1.76 & 2.38 \\
\hline $\begin{array}{l}\text { Calculated Stress } \\
\text { at 40 ton Load } \\
\text { (psi) }\end{array}$ & $1.36 \times 10^{4}$ & $6.7 \times 10^{4}$ & $1.95 \times 10^{5}$ \\
\hline $\begin{array}{l}\text { Maximum } \\
\text { Allowable Stress } \\
\text { (psi) }\end{array}$ & $<1 \times 10^{4}$ & $1.0 \times 10^{5}$ & $1.3 \times 10^{5}$ \\
\hline
\end{tabular}

\subsection{RAMAN PROBE}

The Raman probe shown in Figure 3 and illustrated in detail in Figure 4 contains the basic components required for the in-tank cone penetrometer Raman probe as set forth by WHC-SD-TD-RPT-008 and the findings of the Raman Spectroscopy Peer Review (WHC-EP-0785). The probe consists of a laser band pass filter for the removal of Raman signal generated along the length of the silica laser launch fiber and a laser notch filter for the removal of scattered laser light from the tank waste and other surfaces. The probe will be optimized for use in the near infrared region of the spectrum with a 780 to $800 \mathrm{~nm}$ diode laser source. This wavelength range has been chosen to reduce the potential of fluorescence from the tank waste matrix and to utilize the minimum transmission loses of light through long lengths of optical fibers (900 to 1000 feet). The final configuration of the Raman probe will be determined during FY95 (TTP SF2-1-12-03, subtask 1).

The components of the Raman probe will necessarily be exposed to potentially high radiation fields during in-tank penetrometer deployment. While radiation may cause darkening of optical components, in particular filters, these effects are minimized by utilization of near infrared laser wavelengths. In addition, the time of exposure during penetrometer will be no more than 2 to 3 hours from entry at the tank riser to the bottom of the tank, given a penetrometer push rate of 1 to $2 \mathrm{~cm}$ per second. If radiation proves to be a limiting factor in the usefulness of the penetrometer probe, the use of a gamma ray attenuating material such as tungsten for the Raman probe assembly can be explored. 


\subsection{CONCLUSIONS}

The Raman optical spectroscopic techniques offers an ideal interrogation tool for in-tank cone penetrometer deployment in that no direct physical contact between the sensor and the harsh environment of the Hanford underground storage tank waste materials are necessary, yet specific chemical information may be obtained. This report details a design concept for a Raman cone penetrometer probe assembly for tank deployment. A working penetrometer probe will be fabricated during FY95 based on this design concept.

\subsection{ACKNOWLEDGMENT}

The work at Lawrence Livermore National Laboratory was supported by Sherry M. Gibson, Program Manager of the Underground Storage Tank Integrated Demonstration, EM-50, Office of Technology Development, U.S. Department of Energy. The author thanks of Steve Brown and Mike Delong of LLNL for many useful insights and discussions, and also David Nilson of LLNL on assignment to General Atomics, San Diego, for the calculations on the window materials. 
UCRL-ID-xxxx $x \alpha$

page 6 of 10

APPENDIX A

FIGURES 


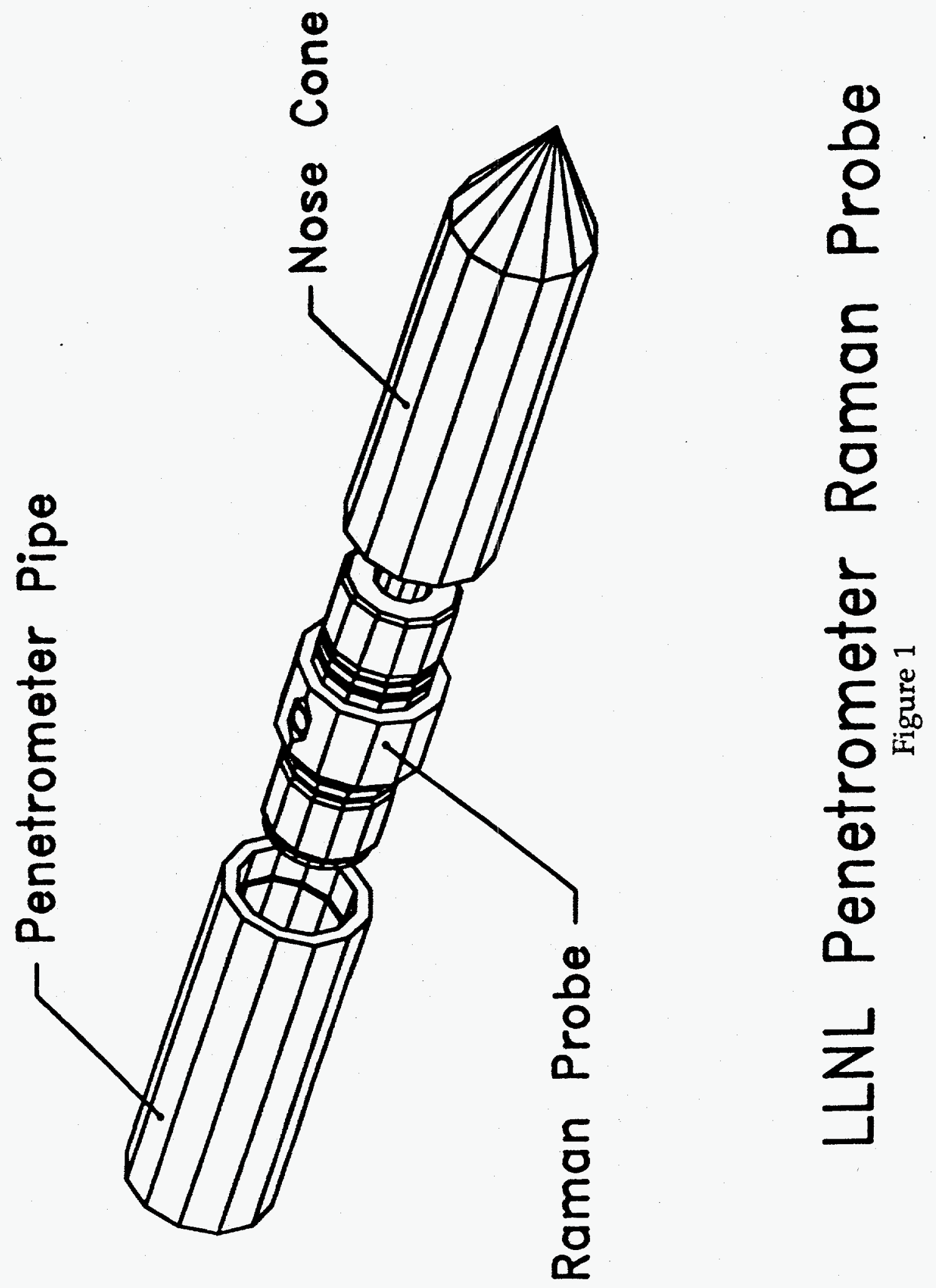




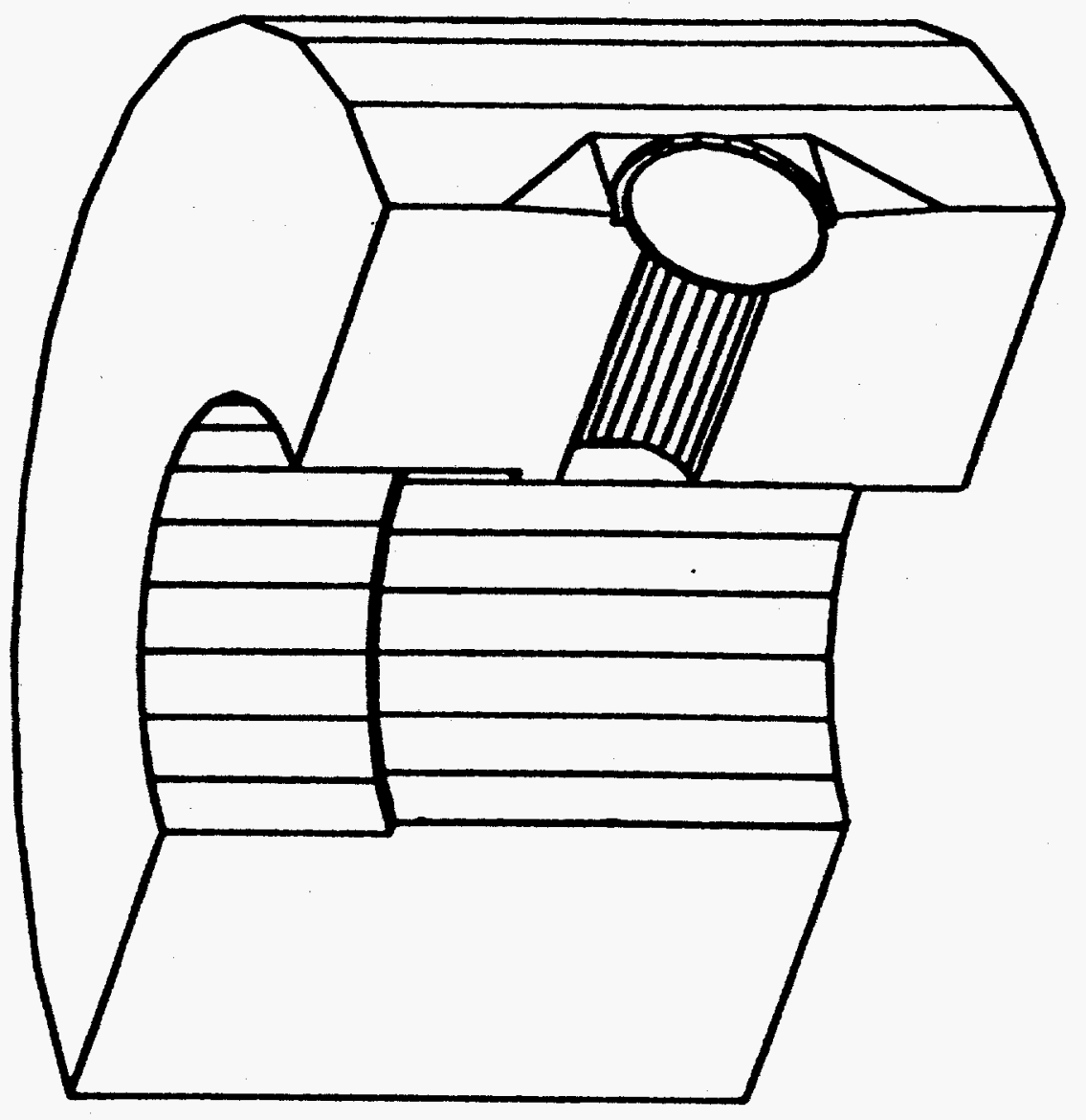

$\frac{5}{50}$

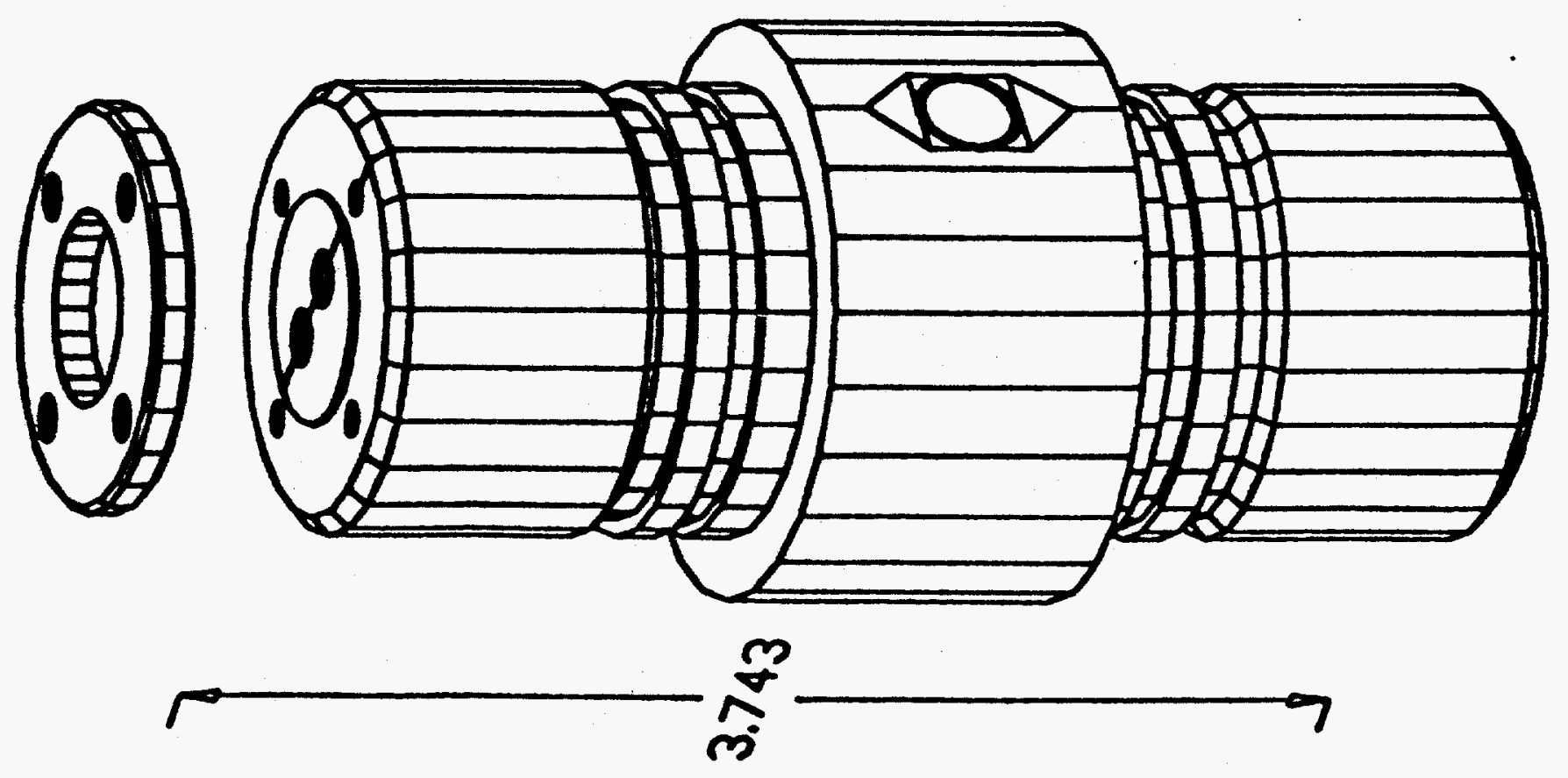




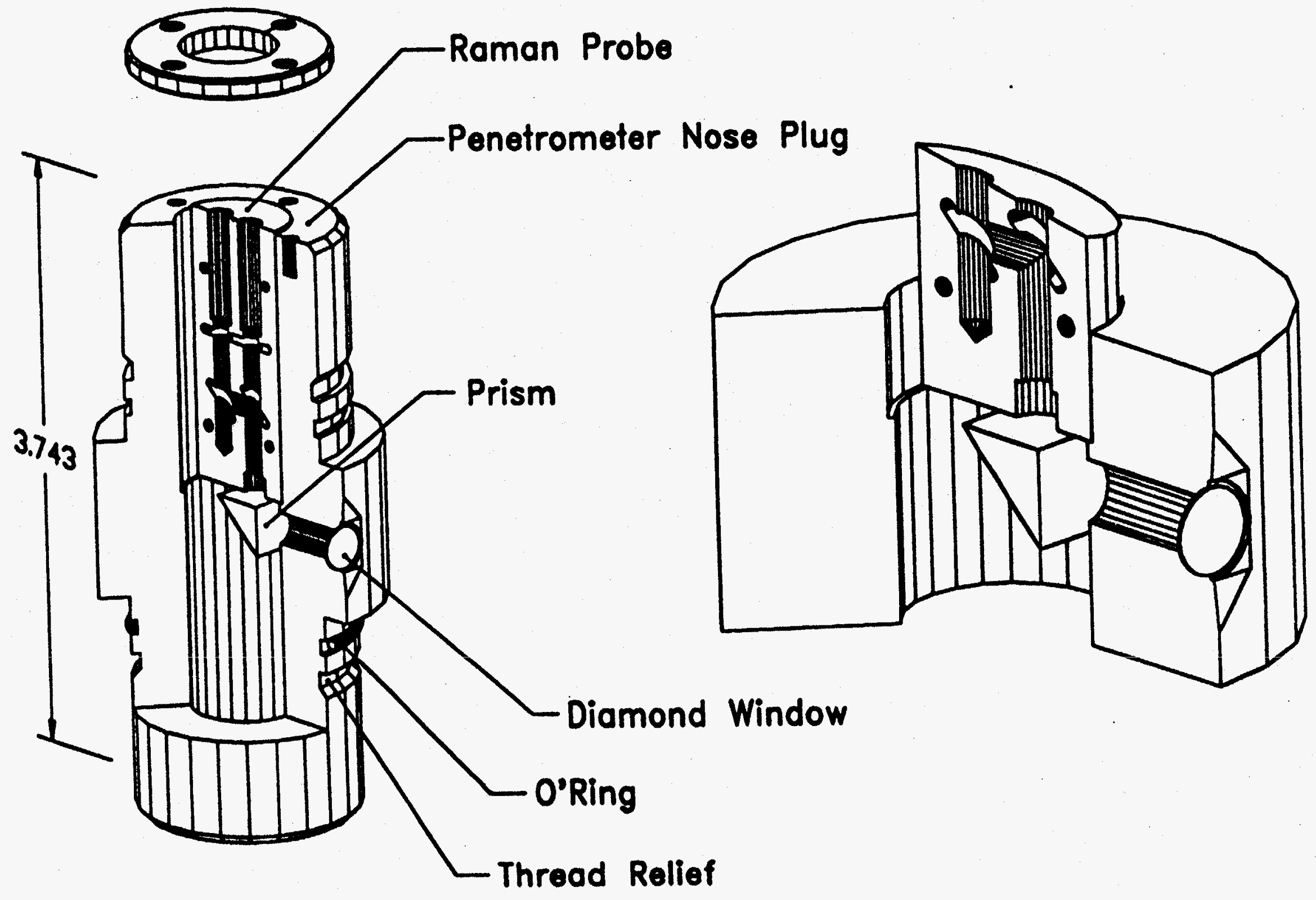

LLNL Penetrometer Raman Probe Figure 3 


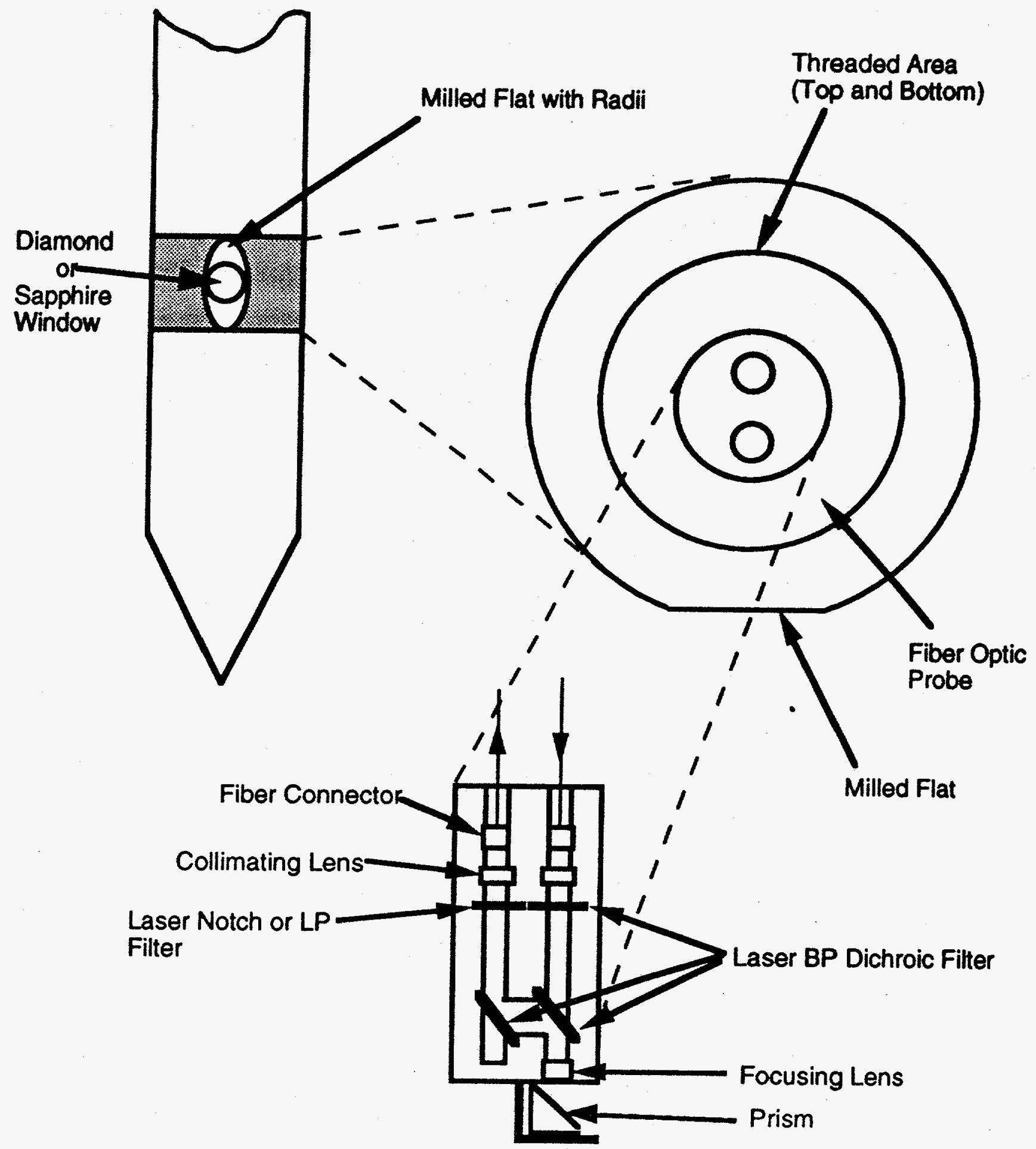

Figure 4 